\title{
Harvesting of measles virus from infected cell culture
}

\author{
Masanobu Yamanaka, Mikio Adachi Eiji Watari, \\ Shoji Kyono and Yukio Yamazi \\ Department of Microbiology and Immunology, Nippon Medical School, Tokyo, Japan
}

Measles virus can be readily adapted to growth in a variety of continuous cell systems of primate origin ${ }^{1-7}$, though isolation of the virus from patients is most successful ${ }^{-}$with primary primate kidniey"). After infection of the virus in stable cell lines, even with large inocula, new virus can not be detected for at least 12 to $15 \mathrm{hrs}$, and another $48 \mathrm{hrs}$ elapse before titers attain peak levels. Once maximal titers are attained, there is a fairly constant amount of virus in the fluid phase of the cultures until all of the cells have been destroyed. At any given time, the intracellular virus content exceeds that of the extracellular fluid; this has been attributed to the thermal degradation of virus released from the cells.

In order to make a fundamental study of the virus, it is necessary to have a stock virus of high infectivity titer. Although measles virions do not exactly mature inside of the cell, some procedures for disruption of the infected cell increase the virus yield. Three methods for harvesting, freezing-thawing, sonication and vigorous dispersion of measlesinfected cells were tested in this paper.

Edmonston strain of measles virus and Vero monolayer culture were used. Preparation of the culture, inoculation of the virus, and method of plaque assay were described elsewhere". Sonication was carried out at $20 \mathrm{kHz}, 60 \mathrm{~W}$ with Ultrasonic Disruptor, Model UR-200 P, Tomy Seiko, Tokyo and dispersing was with MRK-ILADO Labo Disperser, Mitamura Riken, Tokyo.

Experiment 1: Virus was inoculated into Vero monolayer culture in a Roux bottle, and when $\mathrm{CPE}$ (cytopathic effect) was complete, the culture was frozen at $-70^{\circ} \mathrm{C}$. The culture was thawed and cells were scraped with a rubber policeman into the culture fluid. The cell suspension was separated to 4 parts : the first received no treatment; the second was spun at $2000 \mathrm{rpm}$ for $15 \mathrm{~min}$ at $4^{\circ} \mathrm{C}$ to remove cell debris; the third was sonicated for 10,30 , and $60 \mathrm{sec}$; the fourth was dispersed for 10,30 , and $60 \mathrm{sec}$. Sonicated or dispersed samples were spun at $2000 \mathrm{rpm}$ for $15 \mathrm{~min}$ and the supernatants were plaque assayed. Samples were immediately plaque assayed in Vero cell cultures. Infectivity titers of the samples are shown in the Table, Part A. Sonication for $10 \mathrm{sec}$ gave a high titer and dispersing gave rather lower titer. Although the latter treatment for more than $60 \mathrm{sec}$ would give good yield, the prolonged dispersing could give contamination.

Experiment 2: Stock virus should be delivered into many small tubes and kept in a deep-freezer. Infected cell culture showing complete CPE was scraped with a rubber pliceman into the culture medium. Cell suspension was divided into 4 parts. One did not receive any treatment, others were sonicated for 10,30 , and $60 \mathrm{sec}$, and they were stored at $-70^{\circ} \mathrm{C}$. After thawing, the first sample was divided into 2 parts, one was spun at $2000 \mathrm{rpm}$ for 
Measles virus yield with various treatment of infected cell culture

\begin{tabular}{|c|c|c|c|c|}
\hline & \multicolumn{2}{|c|}{ Treatment } & $\mathrm{PFU}^{*} / 0.1 \mathrm{ml}$ & 96 \\
\hline \multirow[t]{8}{*}{ A } & \multicolumn{2}{|c|}{ Cell suspension } & $1.2 \times 10^{5}$ & 100 \\
\hline & \multicolumn{2}{|c|}{ Supernatant of cell suspension } & $6.2 \times 10^{4}$ & 51.7 \\
\hline & \multirow[t]{3}{*}{ Sonication } & $10 \mathrm{sec}$ & $1.6 \times 10^{5}$ & 133.3 \\
\hline & & $30 \mathrm{sec}$ & $1.1 \times 10^{5}$ & 91.7 \\
\hline & & $60 \mathrm{sec}$ & $1.8 \times 10^{4}$ & 15.0 \\
\hline & \multirow[t]{3}{*}{ Dispersing } & $10 \mathrm{sec}$ & $2.6 \times 10^{4}$ & 21.7 \\
\hline & & $30 \mathrm{sec}$ & $4.3 \times 10^{4}$ & 35.8 \\
\hline & & $60 \mathrm{sec}$ & $6.9 \times 10^{4}$ & 57.5 \\
\hline \multirow[t]{5}{*}{ B } & \multicolumn{2}{|c|}{ Cell suspension } & $1.6 \times 10^{5}$ & 100 \\
\hline & \multicolumn{2}{|c|}{ Supernatant of cell suspension } & $2.2 \times 10^{5}$ & 137.5 \\
\hline & \multirow[t]{3}{*}{ Sonication } & $10 \mathrm{sec}$ & $2.5 \times 10^{5}$ & 156.3 \\
\hline & & $30 \mathrm{sec}$ & $1.5 \times 10^{5}$ & 93.8 \\
\hline & & $60 \mathrm{sec}$ & $2.8 \times 10^{5}$ & 175 \\
\hline \multirow[t]{6}{*}{$\mathrm{C}$} & \multicolumn{2}{|c|}{ Cell suspension } & $2.4 \times 10^{4}$ & 100 \\
\hline & \multicolumn{2}{|c|}{ Supernatant of cell suspension } & $3.0 \times 10^{4}$ & 125.0 \\
\hline & \multirow[t]{4}{*}{ Sonication } & $5 \mathrm{sec}$ & $4.6 \times 10^{4}$ & 191.7 \\
\hline & & $10 \mathrm{sec}$ & $4.5 \therefore 10^{4}$ & 187.5 \\
\hline & & $20 \mathrm{sec}$ & $3.3 \times 10^{4}$ & 137.5 \\
\hline & & $30 \mathrm{sec}$ & $3.1 \times 10^{4}$ & 129.2 \\
\hline
\end{tabular}

A : Infected cell culture was frozen-thawed.cells were scraped treated and plaque assayed.

B : Infected cells were scraped, the cell suspension was treated, stored at $-70^{\circ} \mathrm{C}$, thawed, centrifuged and plaque assayed.

C : Infected cells were scraped, treated, centrifuged, stored at $-70^{\circ} \mathrm{C}$, and plaque assayed.

* (Plaque forming unit.)

$15 \mathrm{~min}$ to obtain the supernatant of light centrifugation and the other received no treatment, and infectivity titers of all samples were plaque assayed. Table, Part B suggests that virus was released from scraped cells with freezing-thawing as was with the sonication, and sonication for $60 \mathrm{sec}$ did not decrease the infectivity titer, but delivering of infected cell suspension or of sonicated material without centrifugation may not give the homogeneity among tubes.

Experiment 3 : Similar experiment to Exp. 2 was carried out, but samples were spun and the supernatants was stored at $-70^{\circ} \mathrm{C}$ before the plaque assay. Table, Part $\mathrm{C}$ suggests that sonication for 5 to $10 \mathrm{sec}$ gave good yield of infective virus.

From these experiments, it is recommended that for preparation of the experimental measles virus stock, an infected culture is scraped, cell suspension is sonicated for 5 to $10 \mathrm{sec}$, supernatant of light centrifugation is delivered into tubes and stored at $-70^{\circ} \mathrm{C}$.

\section{REFERENCES}

1) Black, F.L., Reissing, M., and Melnick, J.L. : Proc. Soc. Exp. Biol. Med., 93, 107, 1956

2) Dekking, F., and McCarthy, K. : Proc. Soc. Exp. Biol. Med., 93, 1, 1956

3) DeMaeyer, E. : Virology, 11, 634, 1960.

4) Frankel, J.W., and West, M.K. : Proc. Soc. Exp. Biol. Med., 97, 741, 1958.

5) Kohn A., and Yassky, D. : Virology, 17, 157, 1962.

6) Underwood, G.E. : J. Immunol., 3, 198, 1959.

7) Shishido, A., Yamanouchi, K., Hikita, M., Sato. T., Fukuda, A., and Kobune, F. : Arch, Ges. Virus. forsch., 22, 364, 1967.

8) Enders, J.F. : Am. J. Dis. Child., 103, 282, 1962.

9) Yamazi, Y., Black, F.L., and Watari, E. : J. Nippon Med. Sch., 44, 292, 1977. 